\title{
Critical Debates
}

\section{Indigenous Parties and Democracy in Latin America}

Raúl L. Madrid

\begin{abstract}
In recent years, important indigenous parties have emerged for the first time in Latin American history. Although some analysts view this development with trepidation, this essay argues that the indigenous parties in Latin America are unlikely to exacerbate ethnic conflict or create the kinds of problems that have been associated with some ethnic parties in other regions. To the contrary, the emergence of major indigenous parties in Latin America may actually help deepen democracy in the region. These parties will certainly improve the representativeness of the party system in the countries where they arise. They should also increase political participation and reduce party system fragmentation and electoral volatility in indigenous areas. They may even increase the acceptance of democracy and reduce political violence in countries with large indigenous populations.
\end{abstract}

$\mathrm{I}$ $n$ recent years, Latin America has witnessed the emergence of important ethnic parties for the first time in its history. In Bolivia, Evo Morales, the 2002 presidential candidate of a new indigenous party known as Movement to Socialism (MAS), finished second in the elections. In Ecuador, the Pachakutik Plurinational Unity Movement helped elect Lucio Gutiérrez president in 2002. Important ethnic parties have also emerged in the last two decades in Colombia, Nicaragua, and Venezuela.

The indigenous parties differ substantially from the parties that have long dominated Latin American politics in that they have explicitly sought to represent the interests of the long-ignored and subordinated indigenous population. Many people have therefore welcomed the emergence of these parties. Nevertheless, some observers fear that the new parties, and the powerful indigenous organizations that back them, may exacerbate ethnic conflict and destabilize democracy in the region. Critics of the indigenous parties and organizations decry the indigenous movements for rejecting Western culture and for precipitating uprisings that have led to the overthrow of elected presidents in Ecuador and, more recently, Bolivia. These critics are concerned about links between 
the indigenous movements and radical leftist groups, and they fear that indigenous uprisings in the region could spread (Oppenheimer 2003; Latin American Andean Group Report 2003; Latin American Weekly Report 2003).

Are these concerns well founded? What impact will the new indigenous parties have on the consolidation of democracy in the region? This essay argues that indigenous parties in Latin America are unlikely to exacerbate ethnic conflict or create the kinds of problems that have been associated with some ethnic parties in other regions. To the contrary, the emergence of indigenous parties in Latin America may help deepen democracy in the region. This essay focuses primarily on MAS and Pachakutik, the two most important indigenous parties to emerge in Latin America to date. Nevertheless, one would expect the argument developed here to apply to any major indigenous party in the region.

\section{Ethnic Parties and Ethnic Polarization}

The political science literature on ethnic parties would lead us to view the emergence of indigenous parties in Latin America with some concern. The dominant strain of this literature is highly critical of ethnic parties, which are typically defined as parties that cater primarily to a single ethnic group or cluster of ethnic groups. ${ }^{1}$ This literature suggests that ethnic parties will often provoke ethnic polarization and conflict because their leaders have incentives to make incendiary communal appeals (Rabushka and Shepsle 1972; Horowitz 1985; Sisk 1996; Reilly 2002). Horowitz, for example, argues that "by appealing to electorates in ethnic terms, by making ethnic demands on government, and by bolstering the influence of ethnically chauvinistic elements within each group, parties that begin by merely mirroring ethnic divisions help to deepen and extend them" $(1985,291)$.

Critics of ethnic parties maintain that ethnic parties will not typically be able to attract votes from outside their own ethnic group because of the fixity and sharpness of ethnic group boundaries and the intensity of ethnic group preferences (Horowitz 1985; Rabushka and Shepsle 1972). ${ }^{2}$ According to Horowitz, an ethnic party, "recognizing that it cannot count on defections from members of the other ethnic group, has the incentive to solidify the support of its own group" $(1985,318)$. Leaders of ethnic parties will concentrate on mobilizing voters from their own ethnic group by appealing to ethnic prejudice and resentments and by exaggerating the threat represented by other ethnic groups. Moderate leaders of ethnic parties will quickly be displaced by more extremist leaders in the process that has come to be known as outbidding. As Sisk $(1996,17)$ portrays it: "Extremist leaders, seeking to capitalize on mass resentment, outbid moderates by decrying acts of accommodation as a 
sellout of group interests, citing collective betrayal and humiliation." Such appeals typically cause interethnic relations to deteriorate, leading, at times, to outright conflict. Increasing ethnic polarization, in turn, makes it difficult for nonethnic parties to subsist. As a result, Horowitz and others suggest, the emergence of ethnic parties may lead to the disappearance of nonethnic parties.

This doomsday scenario seems unlikely to occur in Latin America, however, in large part because ethnic identities in the region are characterized by a great deal of fluidity and ambiguity. In most Latin American countries, mestizos-that is, people of mixed European and indigenous descent-are the single largest population group, which has helped blur the lines between ethnic categories. Latin America also has a large population that is partly of African descent, which has further clouded the boundaries between different races and ethnicities.

The dominant mestizo population in Latin America has often adopted a contradictory attitude toward its own indigenous ancestry and culture. On the one hand, many mestizos have implicitly accepted their own indigenous roots and have celebrated many of the achievements and legacies of indigenous cultures as part of their national heritage. On the other hand, they have typically not identified themselves as indigenous, and they have frequently looked down on and discriminated against people they do identify as indigenous.

Who has identified themselves as indigenous (or has been identified as indigenous) in Latin America has changed over time and place, depending on numerous factors. In the 1900s, many indigenous people in the countryside in Latin America began to identify themselves as campesinos (peasants), partly because of state efforts to organize them into peasant sectors (Yashar 1999). Other indigenous people migrated to the cities, where they frequently shed their indigenous identities. More recently, a process of "reindianization" is taking place in much of Latin America as large numbers of people, including individuals who are only partly of indigenous ancestry, have begun to adopt the indigenous label. Even today, however, many people who are mostly or wholly of indigenous ancestry do not identify as indigenous or will do so only under certain circumstances. In recent surveys and censuses in Bolivia, for example, the percentage of people who are willing to identify themselves as indigenous has ranged from 18 to 62 percent, depending in large part on what choices are offered (INE 2001; Seligson 2002; PNUD 2004). ${ }^{3}$

The fluidity and ambiguity of ethnic identities in Latin America means that nonethnic or multiethnic parties are likely to retain considerable appeal. Individuals who do not fully identify with a single ethnic group or do so only under certain circumstances may be reluctant to vote for an ethnic party. Even those who do identify with a single ethnic group may be reluctant to cast their votes solely on the basis of their ethnic identity 
in an environment where ethnic identities are unstable and ambiguous. Therefore, the emergence of indigenous parties in Latin America is unlikely to lead to the disappearance of nonethnic parties. Indeed, nonethnic parties continue to win the vast majority of votes, even in those Latin American countries where important indigenous parties have emerged. Moreover, nonethnic parties continue to do well in indigenous areas in these countries. Nonethnic parties, for example, won almost 60 percent of the vote in majority indigenous provinces in the 2002 Bolivian legislative elections and more than 60 percent of the vote in majority indigenous counties in the 2002 legislative elections in Ecuador. ${ }^{4}$

Nor is the emergence of indigenous parties likely to bring on an ever-worsening spiral of incendiary communal appeals that lead inexorably to ethnic polarization and conflict. The lack of clear boundaries between ethnic groups in Latin America means that leaders of ethnic parties in the region have the potential to attract support from people of diverse racial and ethnic origins. Indigenous parties, for example, might attract votes from people who do not identify as indigenous but may have partial or entirely indigenous ancestry, or they may attract support from people who are not of indigenous descent but identify with indigenous culture and support some of the demands of the indigenous movements. They may also attract support from individuals who do not identify with the indigenous cultures or movements but support the parties' stances on other issues. For this reason, incendiary communal appeals are likely to be counterproductive. Such appeals would not only risk antagonizing potential supporters from other ethnic groups, but might also alienate indigenous voters who do not have strong indigenous identities or who have close ties to people from other ethnic groups. ${ }^{5}$

This does not mean that no indigenous parties will make radical communal appeals. Indeed, some indigenous parties have adopted a radical ethnonationalist discourse. It does mean, however, that the radical ethnonationalist parties are unlikely to win the allegiance of numerous voters, even within their own ethnic group; and as a result, they should have a limited impact on the national political environment. To win large numbers of votes in an environment where ethnic identities are fluid and ambiguous, indigenous parties need to adopt pragmatic and inclusive approaches to politics, which is precisely what the most successful indigenous parties have done.

To date, the indigenous parties that have performed best in elections in Latin America-MAS in Bolivia, Pachakutik in Ecuador, and Alianza Social Indígena (ASI) in Colombia-have largely avoided incendiary rhetoric that could alienate members of other ethnic groups. To the contrary, these parties have actively sought to woo nonindigenous along with indigenous voters. As Dionisio Nuñez, a congressional rep- 
resentative of MAS, put it, MAS is "an inclusive not an exclusive party ...we did not want to go from being excluded to excluding others" (2004). All these parties have recruited nonindigenous as well as indigenous candidates for office, and Pachakutik has formed electoral alliances with important nonindigenous parties. Efforts to woo nonindigenous voters have been largely successful. Data from Bolivia and Ecuador suggest that both MAS and Pachakutik attracted many nonindigenous supporters in the 2002 elections. ${ }^{6}$ The same appears to be true in Colombia. Indeed, Van Cott $(2004,292)$ suggests that indigenous parties in Colombia have received more votes from nonindigenous people than from indigenous people.

Not all indigenous parties have made efforts to attract support from the nonindigenous population, however. Ethnic parties, such as Yapti Tasba Masrika Nani (YATAMA) in Nicaragua and the Pueblo Unido Multiétnico de Amazonas (PUAMA) in Venezuela, have focused largely on attracting support from members of their own ethnic groups (Rizo Zeledón 1990; Van Cott 2004, 292). Even these parties, however, have largely avoided polarizing rhetoric and have sought to work with nonethnic parties and governments. YATAMA, for example, forged alliances with the UNO government in Nicaragua and subsequently with the Sandinistas, while PUAMA has cooperated with the left-wing Patria Para Todos (PPT) party, as well as with the administration of Hugo Chávez (Hooker 2001; Van Cott 2004, chap. 6).

A few indigenous parties and leaders have expressed hostility to the nonindigenous population, but these parties have traditionally fared extremely poorly in elections in Latin America, even among the indigenous voters they claim to represent. The radical Indianista parties in Bolivia, for example, never obtained more than 2 percent of the vote in national elections. The Movimiento Indígena Pachacuti (MIP), a Bolivian indigenous party whose leader, Felipe Quispe, has at times voiced hostility to nonindigenous people, did win 6 percent of the national vote in the 2002 Bolivian elections, but Quispe toned down some of his inflammatory rhetoric during the campaign (Van Cott 2004: Chapter 5). Even MIP, moreover, won only 8 percent of the vote in majority indigenous provinces in Bolivia in the 2002 elections, and it has since largely fallen apart. ${ }^{7}$ The failure of the exclusionary indigenous parties to attract support from most of the indigenous population has meant that even these parties have not significantly worsened interethnic relations in Latin America, although they certainly have not improved matters.

Instead of undermining democracy in the region, the emergence of important indigenous parties in Latin America may actually help bolster it in a number of ways. The indigenous parties will certainly improve the representativeness of the party system in the countries where they arise. The major indigenous parties should also increase political partic- 
ipation and reduce party system fragmentation and electoral volatility in indigenous areas. These parties may even increase the acceptance of democracy among the indigenous population and reduce political violence in areas with large indigenous populations, although whether these latter two benefits are realized will depend largely on the actions of the leaders of the indigenous parties. Each of these potential benefits merits discussion.

\section{Improving Political Representation}

The emergence of indigenous parties in Latin America should deepen democracy in the region by providing a voice to a politically and socioeconomically marginalized group that represents a large portion of the population in some Latin American countries. The indigenous population in Latin America ranks well below the nonindigenous population on virtually all major indicators of socioeconomic development, including income, education, health, and housing. Indigenous people, moreover, have traditionally had little political influence. Throughout much of their history, the major parties in Latin America have ignored indigenous voters or have wooed them principally through clientelistic appeals. Some important parties have channeled patronage resources to indigenous leaders, organizations, or communities, but, until recently, they rarely embraced key indigenous demands on issues such as agrarian reform, multicultural education, and regional autonomy.

The major nonethnic parties in Latin America have also traditionally failed to recruit many indigenous people as candidates for electoral office or for leadership positions in the party hierarchy, although they have fielded indigenous candidates for local offices in many instances. Various parties have made some progress in this area in recent years, but the indigenous population is still significantly underrepresented in most countries. In Guatemala, for example, only about 11 percent of legislators in 2000 were indigenous (ASIES 2000, 46). This constitutes a significant 'increase from earlier periods, but it still represents a very small percentage in a country where indigenous people represent approximately half of the total population.

The indigenous parties, by contrast, have selected large numbers of indigenous people as candidates for important political offices and for leadership positions in the parties themselves. Approximately 85 percent of MAS's representatives in the legislature are indigenous, including Evo Morales, the party's presidential candidate in 2002 (Rivera Pinto 2002, 52). Most of the leaders of Pachakutik, including its representatives in the legislature, are indigenous, although Pachakutik has also supported nonindigenous candidates from other parties in presidential elections. Pachakutik originally intended to run an indigenous candidate in the 
2002 presidential elections, but internal divisions made it impossible to agree on a candidate, and the party ultimately decided to support Lucio Gutierrez of the Patriotic Society Party (PSP), a new nonethnic party. Gutiérrez was an army officer who had come to fame as the leading military supporter of the indigenous uprising that overthrew Ecuadorian president Jamil Mahuad in early 2000.

Both MAS and Pachakutik have styled themselves as the authentic representatives of the indigenous population, and they have maintained close relations with the indigenous organizations from whence they sprang. The Confederation of Indigenous Nationalities of Ecuador (CONAIE) and the unions of coca growers in Bolivia have played an important role in shaping the parties' programs, although tensions have also surfaced from time to time between these organizations and the indigenous parties that they helped create. MAS and Pachakutik have advocated a broad left-wing agenda, including strong opposition to neoliberal reforms. However, they have also placed a great deal of emphasis on issues that have traditionally been important to indigenous movements, such as agrarian reform, local autonomy, and, in the case of MAS, the cultivation of coca. Morales, for example, has argued, "it is necessary to achieve total rights to the land and territory, where the indigenous make decisions and administer natural resources" (Rivero Pinto 2002, 25).

The emergence of indigenous parties in Bolivia and Ecuador thus has placed indigenous demands at the forefront of the policy agenda and has given indigenous people an important voice in policy affairs. Indigenous parties cannot possibly represent all indigenous people, and the more moderate of these parties, such as MAS and Pachakutik, may not represent the more militant members of the indigenous population. Nevertheless, by forcefully advocating the demands of a significant sector of that population, these parties have clearly improved the representation of indigenous people in the political system. Their success has also put pressure on the main nonethnic parties to pay more attention to those demands in order to stem the loss of indigenous votes. Some of these nonethnic parties have therefore recruited more indigenous candidates for political offices and have adopted some indigenous demands in their platforms and programs. Indeed, even in those countries where significant indigenous parties have not yet emerged, nonethnic parties have increasingly embraced indigenous demands in an effort to solidify their support in indigenous areas.

\section{Expanding Political Participation}

The emergence of indigenous parties should increase voter turnout among the indigenous population in Latin America. Indigenous people have tended to vote at significantly lower rates than nonindigenous 
people in the region. A recent study found that the proportion of the population that is indigenous had a statistically significant negative impact on voter turnout at the municipal level in the 1990 and 1995 presidential and legislative elections in Guatemala (Lehoucq and Wall 2001). ${ }^{8}$ In Mexico, voter turnout has also tended to be lower in indigenous municipalities than in nonindigenous ones (Ruíz Mondragón 1998). In the 2000 elections, for example, only 59.5 percent of the population over 18 years old voted in municipalities that were mostly indigenous, as opposed to 64.4 percent in municipalities where indigenous people represented a minority. ${ }^{9}$ Voter turnout has also traditionally been lower in indigenous than in nonindigenous areas in Bolivia and Ecuador.

The lower voting rates have a number of causes. First, a significant percentage of indigenous people do not speak or read Spanish, which can be a substantial impediment to both registration and voting. Second, a disproportionately large number of indigenous people live in rural areas and therefore have to travel longer distances to vote or to register. Third, some Latin American countries have imposed significant financial or bureaucratic hurdles to voter registration, which affect the indigenous population particularly severely because they tend to have limited financial resources. In Bolivia, for example, citizens must obtain identity cards in order to vote, but these cards are costly and not easily obtained in rural areas (Van Cott 2003; Ticona et al. 1995, 181-85). ${ }^{10}$ Fourth, the traditional failure of the major parties to cater to the interests of indigenous people has also probably depressed turnout among this population. Some indigenous people may not vote or even register to vote because they do not have much enthusiasm for any of the parties or the candidates. ${ }^{11}$

The emergence of indigenous parties, however, should boost voter turnout among indigenous people by giving them a greater stake in the elections. More indigenous people will presumably turn out for elections in which candidates or parties specifically seek to represent them. Indigenous parties should also work hard to boost voter registration and turnout in indigenous areas, because the indigenous population typically forms the core of their electoral support. Indigenous parties, for example, may seek to reduce both the financial and bureaucratic obstacles to voter registration through changes in the electoral laws or government policies. In order to facilitate the turnout of indigenous voters, indigenous parties might also push to expand voting centers to more rural areas and to create ballots that are easily understandable to those who do not read Spanish. Indigenous parties will presumably engage in large voter registration and "get out the vote" drives in indigenous areas in order to maximize the number of votes they receive.

The rise of indigenous parties appears to have already increased voter turnout among the indigenous population in Bolivia and Ecuador, 
although other factors may also be partly responsible. Between 1992 and 2002, the number of votes cast in Ecuadorian counties (cantones) where the indigenous population represented the majority rose by 86 percent, as opposed to only 54 percent in counties where indigenous people are in the minority. As a result, turnout in indigenous areas in Ecuador now exceeds turnout in nonindigenous areas. (Turnout is measured here as a percentage of registered voters.) Turnout levels in counties that are majority indigenous have averaged 69 percent since 1996, as opposed to only 67 percent in counties that are less than 50 percent indigenous. Before the emergence of Pachakutik in the mid1990 s, however, turnout was lower in nonindigenous than in indigenous areas. In the 1992 Ecuadorian elections, for example, voter turnout was 65 percent in counties where the indigenous population represented a majority and 69 percent in counties where indigenous people were in the minority.

The emergence of a nationally competitive indigenous party has also significantly increased the number of indigenous voters in Bolivia. Between the 1997 and the 2002 elections, the number of votes cast rose by 35 percent in provinces that are majority indigenous, as opposed to only 21 percent in provinces where indigenous people are in the minority. Turnout, measured as a percentage of the voting-age population, rose from 49.9 percent in 1997 to 55.5 percent in 2002 in majority indigenous provinces, but it actually declined by one percentage point, from 56.7 to 55.7 percent, in minority indigenous areas during this period. ${ }^{12}$ MAS and MIP both undertook a variety of efforts to increase turnout in their strongholds in the 2002 elections, as well as to encourage members of these communities to register to vote (Quispe 2004; Pedrero 2004; Torrico 2004). Thus, in both Bolivia and Ecuador, the rise of indigenous parties has helped mobilize the indigenous electorate.

\section{REDUCING Electoral VOLATHITY AND PARTY System Fragmentation}

Indigenous parties in Latin America might also help build more stable and cohesive party systems in countries that have large indigenous populations. As Van Cott has shown, the Latin American countries with proportionally large indigenous populations tend to have poorly institutionalized party systems (Van Cott 2000, 155-74). Bolivia, Ecuador, Guatemala, and Peru all have extremely high levels of electoral volatility (the net change in votes, or seats, among parties between elections), which is one commonly used measure of party system institutionalization. All four of these countries also have highly fragmented party systems. Indeed, between 1980 and 2000, Bolivia, Ecuador, and Guatemala had the most fragmented party systems in the entire region, measured 
in terms of the effective number of parties in presidential elections (Payne et al. 2002, 73). The high levels of electoral fragmentation and volatility have complicated democratic governance in these countries, making it difficult to enact legislation and to sustain policies and programs over time.

This situation has various causes, institutional factors among them; but the voting patterns of the indigenous population in these countries have certainly contributed to the problem. In all four countries, electoral volatility and party system fragmentation have typically been higher in municipalities or provinces where indigenous people represent a large proportion of the population. For example, from 1985 to 1997, Bolivian provinces where indigenous people represented less than one-third of the population had an average of 3.3 effective parties, whereas provinces where the indigenous constituted more than two-thirds of the population had an average of 4.7 effective parties. During this same period, electoral volatility averaged 24 percent in the provinces with less than one-third indigenous population and 42 percent in those with more than two-thirds indigenous population. ${ }^{13}$

The problem also stems partly from the failure of the major parties to represent adequately the interests of the indigenous population, especially their low indigenous recruitment levels and their failure to embrace indigenous-supported programs and policies. Partly for this reason, none of these parties has been able to gain the enduring loyalties of a large proportion of the indigenous population. Instead of consistently supporting a single party, indigenous voters have shifted their votes frequently among a variety of different parties.

The emergence of indigenous parties, however, has the potential to remedy this situation. Indigenous parties may be able to gain the enduring allegiances of large numbers of indigenous voters, thereby reducing electoral volatility and party system fragmentation in highly indigenous areas (Birnir 2004; Madrid forthcoming). Indeed, the emergence of major indigenous parties in Bolivia and Ecuador has already reduced party system fragmentation in such areas. In Bolivia, the effective number of parties in majority indigenous provinces declined after the rise of MAS, dropping from an average of 4.6 in $1985-97$ to 4.0 in 2002 . The emergence of Pachakutik also led the effective number of parties to decline in majority indigenous counties in Ecuador, from 6.1 in 1992 to 4.8 in the period 1996-2002. In nonindigenous areas in both countries, by contrast, the level of party system fragmentation actually rose during these periods.

\section{INCREASING SUPPORT FOR DEMOCRACY}

The emergence of indigenous parties may contribute to democratic consolidation in Latin America by helping to build support for democracy 
and democratic institutions in the region. Disenchantment with democracy is high throughout Latin America, but it is particularly high in those countries with proportionally large indigenous populations. Surveys conducted in 2002 by Latin Barometer reveal that an average of 50 percent of the population in Bolivia, Ecuador, Guatemala, and Peru prefers democracy to any other kind of government, as opposed to 56 percent regionwide (cited in Lagos 2003, 165). ${ }^{14}$ Only 23 percent of the survey respondents in these countries, on average, stated that they were very or fairly satisfied with democracy, as opposed to 32 percent in Latin America as a whole (Lagos 2003, 166). Similarly, surveys of democratic values carried out by the Latin American Public Opinion Project (LAPOP) at Vanderbilt University found that support for democracy was lower in Bolivia, Peru, and Ecuador than in the other Latin American countries surveyed; namely, Costa Rica, El Salvador, Nicaragua, and Paraguay (Seligson 2001, 54).

Survey data on the political views of the indigenous population in Latin America are relatively scarce, but what material does exist supports the notion that indigenous people are frustrated with the political system and do not feel well represented by the existing parties. In a 1988 survey of the Ecuadorian indigenous population, 46.1 of the respondents said that no party represented their interests (Chiriboga and Rivera 1989, 213). In a 1997 survey in Peru, 48.9 percent of indigenous respondents declared that they had no trust in political institutions, as opposed to only 28.4 of the nonindigenous respondents (Democracy Survey Database 2004). Whereas 34.3 percent of the indigenous respondents in Bolivia said it had no trust at all in political parties in a 1998 survey, less than 29.0 of the nonindigenous population reported similar feelings (Democracy Survey Database 2004). Similarly, a survey carried out in Guatemala in 2001 found that indigenous people expressed significantly less support for the political system, including political parties, than did the nonindigenous (Azpuru 2003).

Public opinion data, however, also indicate that indigenous people continue to prefer democracy to other forms of government. In the 1998 survey in Bolivia, only 27.2 of the indigenous respondents said that a coup would be justified for certain reasons, as opposed to 31.7 of all respondents (Democracy Survey Database 2004). Similarly, in Peru, only 23.1 percent of the respondents who spoke an indigenous language said that a military coup would be justified under some circumstances, as opposed to 26.6 of all respondents (Democracy Survey Database 2004). In a 1998 survey in Guatemala, meanwhile, 28.2 percent of indigenous respondents reported that a military coup would not be justified under any circumstances, as opposed to 33.5 of the nonindigenous respondents (Democracy Survey Database 2004). These data suggest that indigenous people continue to believe in the principle of democracy 
even though they are frustrated with how democratic institutions have functioned to date.

The emergence of indigenous parties might help shore up support for democracy among indigenous people for a number of reasons. Indigenous parties should make elections more meaningful for some indigenous people by enabling them to vote for a party that seeks to represent them. Indeed, the increase in voter participation that has occurred in indigenous areas in Bolivia and Ecuador in recent years suggests that the emergence of indigenous parties has increased interest in the electoral process among indigenous voters in those countries. The rise of indigenous parties will presumably increase the number of indigenous representatives in the legislature, which may, in turn, increase indigenous support for this institution. The electoral success of the MAS and, to a lesser extent, the MIP caused the number of indigenous legislators in Bolivia to grow from 10 in 1997 to 52 (out of 130) in 2002, which has given the Bolivian legislature an important indigenous presence (Albó 2002, 95; Rivero Pinto 2002, 36).

Indigenous leaders may penetrate other governmental institutions as indigenous parties become more powerful, which should boost indigenous support for these institutions, too. In Ecuador, for example, leaders of Pachakutik took over a number of important governmental ministries after the election of Gutierrez, although they were obliged to resign these positions after Pachakutik broke with the Gutiérrez administration.

As indigenous parties become increasingly powerful, more indigenous people may come to believe that they can bring about policy change by working through existing political institutions, which should increase support for democracy. Moreover, to the extent that indigenous parties can effect policy changes that benefit the indigenous population, indigenous support for democratic institutions should grow. One of the reasons that so many members of the indigenous population are frustrated with the existing political institutions is that the lives of many indigenous people have not significantly improved since the return to democracy in the region.

Whether the rise of indigenous parties actually does increase support for democracy among the indigenous population will depend partly on the actions of the party leaders. Those leaders must behave democratically and pragmatically themselves. They must not only respect the existing democratic institutions but also work to diffuse democratic practices at the local level. In addition, they must reach out to nonindigenous citizens and parties, practice good governance, and propose realistic solutions to the problems facing their countries and the indigenous population in particular. 


\section{Reducing Polrtical Violence}

The emergence of indigenous parties may also help reduce political violence involving the indigenous population. Indigenous organizations have participated in many peaceful protests in recent years, but they have also been involved in a significant number of actions that have turned violent, including strikes, demonstrations, roadblocks, and seizures of public or private property. In surveys, indigenous people have also expressed greater support than nonindigenous for these aggressive types of political activities (Seligson 2002, 194-96; Democracy Survey Database 2004).

These protests may have laudable aims, but they have, at times, had destabilizing effects. Many of these activities themselves, such as roadblocks and the seizure of property, are illegal, and the participation of indigenous movements thereby undermines the rule of law. Such actions tend to provoke confrontation with the state and at times have culminated in violence, often initiated by security forces trying to repress the protests. Sometimes these protests have spiraled out of control, directly undermining existing democratic institutions. Indeed, in some cases they have led to the overthrow or resignation of elected presidents.

In Ecuador, indigenous people spearheaded the uprising that led to the removal of President Mahuad in 2000. This revolt began when CONAIE, along with the public sector unions, initiated a series of strikes and marches in late 1999 to protest Mahuad's neoliberal economic and social policies. These protests intensified in January 2000, when Mahuad announced his decision to replace the local currency with the U.S. dollar. CONAIE called for mass protests in Quito, and thousands of its members traveled to the capital to participate. A large number of junior officers in the military, led by Colonel Lucio Gutiérrez, joined in. When the protesters marched on the presidential palace, Mahuad fled, and a junta composed of Gutierrez; the head of CONAIE, Antonio Vargas; and a former Supreme Court judge took control. The coup lasted less than a day, however. The military forced Gutierrez to cede his position to an army general, who promptly handed power over to the vice president, Gustavo Noboa. The indigenous movement in Ecuador thus succeeded in helping to topple a president but failed to take power itself.

Indigenous people also helped to overthrow Bolivian President Gonzalo Sánchez de Lozada. This uprising began in mid-September 2003, when the main indigenous peasant confederation in Bolivia, Confederación Sindical Unica de Trabajadores Campesinos de Bolivia (CSUTCB), organized rural roadblocks to protest Sánchez de Lozada's economic and social policies, particularly the decision to export natural gas to the United States. When government troops tried to break a roadblock, four protesters and a soldier were killed. The largest indigenous 
party, MAS, and the main labor group, the Bolivian Workers' Confederation (COB), then joined in, and with their assistance, protests quickly spread to La Paz and El Alto, the large, mostly indigenous city overlooking La Paz. The government ordered the army to suppress the protests, and in the ensuing clashes, more than 50 people were killed. The repression led Vice President Carlos Mesa and the New Republican Force (NFR), one of the main parties in the ruling coalition, to withdraw their support for the Sánchez de Lozada administration. On October 17, 2003 , an increasingly isolated Sánchez de Lozada resigned, leaving the vice president in control.

The participation of indigenous people and movements in certain kinds of protests can thus have destabilizing effects. The emergence of indigenous parties, however, may reduce the appeal of these protests to both indigenous people and their leaders by increasing the costs and reducing the benefits of such activities. Indigenous people and leaders have sometimes supported demonstrations, strikes, roadblocks, and property invasions partly because they believed that such measures were the only available means to exert pressure on the government. The rise of indigenous parties, however, has enabled indigenous people to express their views more fully at the ballot box, and it has given them some degree of influence in the legislature and even in the executive branch. Indigenous people and leaders have thus acquired ways of making their voice heard that are potentially more powerful than protests.

The costs of protests have traditionally been low for indigenous leaders because they did not need to worry about the electoral impact of such measures. Protests bring potentially high costs for leaders of indigenous parties, however, because such protests risk antagonizing moderate indigenous voters, along with nonindigenous people who might otherwise be inclined to vote for the indigenous parties. Indeed, a variety of surveys suggest that the majority of indigenous as well as nonindigenous people oppose such protests. In a recent survey in Bolivia, for example, only one-third of indigenous respondents voiced support for roadblocks, and only 15 percent of them supported property invasions or takeovers of factories or buildings (Seligson 2002, 194-96). The leaders of indigenous parties, particularly major parties with good electoral possibilities, therefore have strong incentives to discourage or moderate such protests, or at least to distance themselves from the protests when they occur.

The electoral successes of MAS and Pachakutik may have had a moderating effect on their leaders, rendering them more cautious than some of the other indigenous leaders in these countries, although it has certainly not led them to foreswear protests altogether. The leadership of Pachakutik did not participate in the overthrow of Mahuad, nor did the party play a role in the recent overthrow of President Gutiérrez. MAS 
played only a minor and reactive role in the overthrow of Sánchez de Lozada, and may have actually had a moderating effect on the outcome. Antonio Pedrero, the leader of MAS's congressional delegation and its 2002 vice presidential candidate, argues, "We are sure of having acted more rationally than others at that time. We were not the organizers of those mobilizations. There wasn't an organizer, there were various. Many of those leaders spoke about installing a revolutionary triumvirate. ... We wanted a constitutional solution" (2004).

In the immediate aftermath of the overthrow of Sanchez de Lozada, moreover, the MAS served as a moderating force in Bolivia. Indeed, it supported the Mesa administration during its first year in power and largely eschewed protests. Gustavo Torrico, a MAS congressional deputy, explains, "when we did not have a legitimate representative we did not have any option other than fighting in the streets and roads. Afterward we gained a significant [legislative] contingent. We decided in Congress to shift from protests to proposals" (2004). Evo Morales similarly emphasizes that MAS has "decided to reach power by means of the vote, not by arms, nor by insurrectional means" (Economist 2004, 37).

In early 2005, however, relations between Morales and Mesa deteriorated, and the MAS and other organizations initiated a series of protests against the government's policies, which ultimately led to the resignation of President Mesa in June 2005. MAS's actions, which may well hurt the party in the December 2005 general elections, suggest that the incentives of electoral politics are not always sufficient to deter indigenous leaders from participating in protests aimed at obtaining other, more immediate goals.

\section{Conclusions}

This essay has argued that the emergence of major indigenous parties in Latin America does not pose the serious threat to democracy that some commentators have suggested. Not only are the major indigenous parties unlikely to create more ethnic polarization and conflict, but they actually have the potential to contribute to democratic deepening in a number of significant ways. The major indigenous parties, for example, should improve political representation, expand political participation, and reduce party system fragmentation and electoral volatility in countries with large indigenous populations.

Indigenous parties may even boost support for democracy and reduce political violence in countries with large indigenous populations, but whether they do will depend partly on how indigenous leaders reconcile the conflicting pressures they will face as they attempt to develop competitive indigenous parties. On the one hand, leaders will face pressure from indigenous activists and other members of their traditional 
constituencies to participate in protests and to demand radical changes in government policy. On the other hand, they will face significant electoral incentives to moderate their views and actions and to form alliances with mainstream political parties in order to attract more voters and gain political influence. If indigenous leaders follow the former path, they risk not only destabilizing democracy but also limiting their own effectiveness, because radical policies and actions are likely to antagonize many voters and marginalize the new indigenous parties from the mainstream of politics. If they compromise too much, however, they risk alienating their voter base and losing their reason for being. This, too, could destabilize democracy, because it might ultimately worsen the existing levels of democratic disaffection among the indigenous population and lead to the rise of more radical indigenous leaders and organizations. To succeed, therefore, the leaders of indigenous parties will need to navigate carefully the perilous path between compromise and cooptation.

\section{NOTES}

1. A few scholars, however, have suggested that ethnic parties may actually help consolidate democracy, although for very different reasons. See Chandra 2005; Birnir 2004.

2. Constructivists have criticized this primordial approach to understanding ethnicity, arguing that ethnic identities are fluid rather than fixed. For a discussion of what this means for theories of ethnic conflict, see Chandra 2005.

3 . Recent surveys suggest that many people who might, under some circumstances, identify as indigenous will self-identify as mestizo if that option is given to them, including people that speak indigenous languages (INE 2001; Seligson 2002; PNUD 2004).

4. All data comparing electoral results in majority and minority indigenous districts in Bolivia and Ecuador are based on the author's analysis of subnational census and electoral data. The Bolivian data come from FUNDEMOS 1998, Corte Nacional Electoral 2002, and INE 2001. The Ecuadorian data were generously made available to the author by Tribunal Supremo Electoral and Sistema Integrado de Indicadores Sociales of Ecuador.

5. The indigenous population is also unlikely to form a uniform voting bloc because it contains considerable internal diversity, which has sometimes led to significant conflicts and divisions. The indigenous population in Bolivia has already split over which indigenous parties to support. Most of MAS's support has come from Quechua areas, whereas most of MIP's votes have come from Aymara areas.

6. See, for example, the survey data from Bolivia presented in Seligson 2002, 53.

7. MIP fared best in Aymara areas in the departments of La Paz and, to a lesser extent, Oruro. Even in majority Aymara provinces, however, it won only 19.4 percent of the vote, on average. 
8. Boneo and Torres-Rivas (2001) did not find a correlation between the proportion of the population that is indigenous and voter turnout in general elections in Guatemala, but they did not control for other instititutional and socioeconomic factors that affect turnout. They measured turnout as a percentage of registered voters because they, unlike Lehoucq and Wall (2001), did not have access to data on the voting-age population at the municipal level. However, Boneo and Torres-Rivas present survey results indicating that indigenous people are less likely than ladinos to be registered to vote.

9. Author's findings based on an analysis of municipal-level electoral and census data from Mexico.

10. In a 1998 survey, the most common reason indigenous respondents gave for not voting was that they did not have their identity cards (Democracy Survey Database 2004).

11. Where indigenous people feel that they have a stake in elections, however, they may vote at higher rates than nonindigenous people. For example, voter turnout in indigenous municipalities in Guatemala exceeded voter turnout in nonindigenous municipalities for the 1999 referendum (Consulta Popular), presumably because the ballot contained questions about indigenous rights (Boneo and Torres-Rivas 2001).

12. Survey data from Bolivia also support the notion that the emergence of indigenous parties has boosted voter turnout. In a 1998 survey, only 74 percent of indigenous respondents reported voting in the 1997 elections, as opposed to 77 percent of nonindigenous respondents (Democracy Survey Database 2004). In the 2002 elections, however, 85 percent of indigenous respondents reported voting, the same percentage as nonindigenous respondents.

13. Party system fragmentation is measured here using the LaaksoTaagepera index, which is the inverse of the sum of squares of each party's share of the total vote. Electoral volatility is calculated using the Pederson index, which is half of the sum of the net change in the proportion of votes won by each party from one election to another.

14. These data represent unweighted country averages.

\section{REFERENCES}

Albó, Xavier. 2002. Bolivia: From Indian and Campesino Leaders to Councillors and Parliamentary Deputies. In Multiculturalism in Latin America, ed. Rachel Seider. New York: Palgrave Macmillan. 74-102.

Asociación de Investigación y Estudios Sociales (ASIES). 2000. Guatemala: informe analítico del proceso electoral 1999. Guatemala City: ASIES.

Azpuru, Dinorah. 2003. Indigenous. Perceptions of Democracy in Guatemala. Paper prepared for delivery at the 2003 Annual Meeting of the American Political Science Association, Philadelphia, August 28-31.

Birnir, Johanna. 2004. The Ethnic Effect: The Effect of Ethnic Electoral Bebavior on the Political Development of New Democracies. Unpublished mss.

Bolivia. Corte Nacional Electoral. 2002. Unpublished electoral data supplied to the author.

Bolivia. Instituto Nacional de Estadística (INE). 2001. Censo de población $y$ vivienda. <www.ine.gov.bo> (Accessed September 2004) 
Boneo, Horacio, and Edelberto Torres-Rivas. 2001. ¿Por qué no votan los guatemaltecos? Guatemala City: Tribunal Supremo Electoral.

Chandra, Kanchan. 2005. Ethnic Parties and Democratic Stability. Perspectives on Politics 3, 2 (June): 235-52.

Chiriboga, Manuel, and Fredy Rivera. 1989. Elecciones de enero 1988 y participación indígena. Ecuador Debate 17: 181-21.

Democracy Survey Database. 2004. Sponsored by the U.S. Agency for International Development and the Latin American Public Opinion Project. $<$ www.millennium-int.com/newdsd > (Accessed September 2004).

Economist. 2004. A Political Awakening. February 21: 35-37.

Ecuador. Tribunal Supremo Electoral. 2003. Unpublished electoral data.

FUNDEMOS. 1998. Datos estadísticos elecciones generales, 1979-1997. Opiniones y Análisis 31 (February). (entire issue)

Hooker, Juliet. 2001. The Myth of Inclusion: Mestizo Nationalism, Identity Politics, and Citizenship in Nicaragua. Ph.D. diss., Cornell University.

Horowitz, Donald L. 1985. Ethnic Groups in Conflict. Berkeley: University of California Press.

Lagos, Marta. 2003. A Road with No Return. Journal of Democracy 14, 2 (April): 163-73.

Latin American Andean Group Report. 2003. Are Indigenous Uprisings the Latest Domino Theory? November 4: 7-9.

Latin American Weekly Report. 2003. Is "Indigenous Fundamentalism" the New Hemispheric Threat? November 18: 1.

Lehoucq, Fabrice, and David Wall. 2001. ¿La explicación es institucional o sociológica? In Construyendo la democracia electoral en Guatemala, ed. Edelberto Torres-Rivas et al. Guatemala City: FLACSO.

Madrid, Raúl L. Forthcoming. Ethnic Cleavages and Electoral Volatility in Latin America. Comparative Politics.

Nuñez, Dionisio. 2004. Deputy, MAS. Author interview. La Paz, July 21.

Oppenheimer, Andrés. 2003. What Would Latin America Be Without Western Influence? Miami Herald, November 6: 16A.

Payne, Mark J., Daniel Zovatto, Fernando Carrillo Flórez, and Andrés Allamand Zavala. 2002. Democracies in Development: Politics and Reform in Latin America. Washington, DC: Inter-American Development Bank.

Pedrero, Antonio. 2004. Head of MAS congressional delegation. Author interview. La Paz, July 22.

Programa de las Naciones Unidas para el Desarrollo (PNUD). 2004. Interculturalismo y globalización: informe nacional de desarrollo bumano 2004. La Paz: PNUD.

Quispe, Felipe. 2004. Founder of MIP, head of the CSUTCB. Author interview. La Paz, July 29.

Rabushka, Alvin, and Kenneth Shepsle. 1972. Politics in Plural Societies. Columbus: Merril.

Reilly, Benjamin. 2002. Electoral Systems for Divided Societies. Journal of Democracy 13, 2 (April): 156-70.

Rivero Pinto, Wigberto. 2002. Indígenas y campesinos en las elecciones: el poder de la Bolivia emergente. Opiniones y Análisis 60: 11-40. 
Rizo Zeledón, Mario. 1990. El caso de la RAAN. Revista de la Costa Caribe Nicaraguense (July-December): 28-51.

Ruiz Mondragón, Laura. 1998. Los pueblos indios en los comicios federales de 1997. Mexico City: Instituto Nacional Indigenista.

Seligson, Mitchell. 2001. Auditoria de la democracia: Ecuador 2001. Quito: CEDATOS.

- 2002. Auditoria de la democracia: Bolivia 2002. La Paz: Universidad Católica Boliviana.

Sisk, Timothy D. 1996. Power Sharing and International Mediation in Etbnic Conflicts. Washington, DC: U.S. Institute of Peace Press.

Ticona, Esteban, Gonzalo Rojas, and Xavier Albó. 1995. Votos y wipbalas: campesinos y pueblos originarios en democracia. La Paz: Fundación Milenio.

Torrico, Gustavo. 2004. MAS Deputy. Author interview. La Paz, July 22.

Van Cott, Donna Lee. 2000. Party System Development and Indigenous Populations in Latin America: The Bolivian Case. Party Politics 6, 2: 155-74.

- 2003. Institutional Change and Ethnic Parties in South America. Latin American Politics and Society 45, 2 (Summer): 1-40.

- 2004. From Movement to Party: The Transformation of Ethnic Politics in Latin America. Unpublished mss.

Yashar, Deborah. 1999. Democracy, Indigenous Movements, and the Postliberal Challenge in Latin America. World Politics 52 (October): 76-104. 